\title{
Evaluating Teaching Workload of Academic Staff for Optimum and Effective Use of Expertise Resources
}

Abdul Rahim Razalli, Kamarulzaman Kamaruddin, Ong Eng Tek, Wong Kung Teck \& Nurul Ain Mohd Daud

To Link this Article: http://dx.doi.org/10.6007/IJARBSS/v11-i6/10077

DOI:10.6007/IJARBSS/v11-i6/10077

Received: 02 April 2021, Revised: 05 May 2021, Accepted: 19 May 2021

Published Online: 01 June 2021

In-Text Citation: (Razalli et al., 2021)

To Cite this Article: Razalli, A. R., Kamaruddin, K., Tek, O. E., Teck, K. W., \& Daud, N. A. M.(2021). Evaluating Teaching Workload of Academic Staff for Optimum and Effective Use of Expertise Resources. International Journal of Academic Research in Business and Social Sciences, 11(6), 13-26.

Copyright: (c) 2021 The Author(s)

Published by Human Resource Management Academic Research Society (www.hrmars.com)

This article is published under the Creative Commons Attribution (CC BY 4.0) license. Anyone may reproduce, distribute, translate and create derivative works of this article (for both commercial and non-commercial purposes), subject to full attribution to the original publication and authors. The full terms of this license may be seen at: http://creativecommons.org/licences/by/4.0/legalcode

Vol. 11, No. 6, 2021, Pg. 13 - 26

Full Terms \& Conditions of access and use can be found at http://hrmars.com/index.php/pages/detail/publication-ethics 


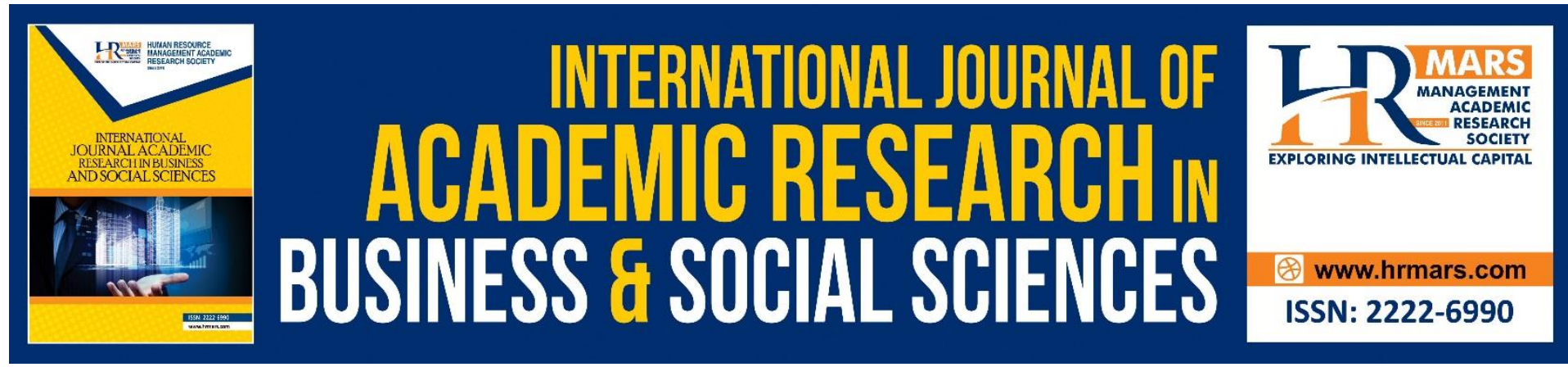

\title{
Evaluating Teaching Workload of Academic Staff for Optimum and Effective Use of Expertise Resources
}

\author{
Abdul Rahim Razalli, Kamarulzaman Kamaruddin, Ong Eng \\ Tek, Wong Kung Teck \& Nurul Ain Mohd Daud \\ Faculty of Human Development, Sultan Idris Education University, 35900 Tanjong Malim, \\ Perak Malaysia
}

\begin{abstract}
This study is to identify teaching workload of academic staff based on teaching load and ratio of academic staff and students to optimize and enhance the use of expertise resources for academic staff at Sultan Idris University of Education (UPSI). The study is quantitative in design with data provided by the Academic Affairs Division (AAD) and the Institute of Graduate Studies (IPS). The study sample involved all UPSI academic staff involving 9 faculties for study semesters of 171 and 172 . The study found that the teaching load for both semesters exceeds 50 percent of the teaching load or 20.9 hours from 40 hours of weekly workload. Findings on ratio of 1:30 academic staff with students for the diploma program found that three diploma programs were still short of lecturers and seven programs were found to have extra lecturers for semester 172 and semester 171. For the Bachelor's degree program with a ratio of 1:25 of lecturers and students found 31 programs from 23 departments short of lecturers while 8 departments have extra lecturers. With a ratio of 1:20 graduate programs (masters) it was found that 14 programs from 24 departments were still short of lecturers and 10 departments with extra lecturers for semester 172 . As for semester 171 , there are 16 departments still short of lecturers and 8 departments with extra lecturers. Implications of the study indicate imbalance of amount in teaching load and the non-compliance of ratio value between lecturers and students that could hamper efforts taken by UPSI to optimize and strengthen the use of existing expertise resources.
\end{abstract}

Keyword: Teaching Load, Academic Staff, Ratio, Expertise Resources and Optimum.

\section{Introduction}

Excessive workload problems are one of the factors that influence the quality and performance of teaching. The load of teaching among academic staff is often associated with regular and non-routine workloads such as conducting research in teaching, community service activities, writing and publishing to enhance quality and professionalism as an academic staff (Benjamin \& Olajumoke, 2013; Markom et al., 2011). Teachings in university involve tasks such as planning, management, delivery, mentoring, and assessment with the aim of disseminating knowledge or skills to students in an effective way. Thesis supervision and monitoring is a task that can assist a lecturer to develop ideas and knowledge through 
research carried out at undergraduate and postgraduate level. The academic staff is the person responsible for various tasks to ensure that an institution continues to fulfill its own mission. Today, the profession of academic staff in the field of higher education in Malaysia is increasingly challenging and complex. According to Markom et al (2011), lecturers in public universities are pressured with a variety of official duties and responsibilities. The multi roles are due to interpersonal demands as well as high expectations of job demands.

Issues on workload of academic staff were also reviewed by Basarudin et al (2016). This study analyzes the issue of workload based on transformation taking place in the Malaysian higher education system in terms of ranking and KPI. Based on thematic analysis from interviews conducted with top management from four categories of universities namely APEX, Research University, Focused University and Comprehensive University, it was found that workload among academic staff has increased from teaching overtime to other responsibilities including research, consulting, administration and community work with little benefit given to them. This study proposes that the workload of academic staff to be reevaluated by suggesting several aspects of improvement and benefits for them, including workload standards to minimize their excess workload in the academic field.

Some universities abroad have their own model to come up with principles of workload for academic staff. Based on a model practiced at the University of South Wales United Kingdom (2014) there are several principles that cover academic workload, supervision and teaching. Reports on workload of academic staff at several local universities in Malaysia state that there are three components to the workload: the teaching and supervision component, the research component, and the administrative component. According to the report on Academic Workload Guidelines from Tun Hussein University (Center for Academic Development and Training, 2016), UTHM allocates a minimum of 40 hours of workload per week to carry out three components of the workload, namely teaching components (lecture, tutorial, and practical) and supervision of Diploma and Bachelor level projects as well as Industrial Training or Teaching Training, a research component that refers to undergraduate and Doctoral Philosophy research and supervision as well as administrative components.

It was also found that lecturers needed to hold administrative positions at university, faculty or department levels. Recognizing their expertise and experience, the services of lecturers are highly valued to facilitate smooth management and administration. Among the roles of academic staff are performing the duties of Dean, Deputy Dean, Head of Department and Head of Responsibility Center (PTJ), carrying out teaching and learning at various levels, conducting field research, doing community service, writing and academic publishing, improving quality and professionalism as academicians and other assignments from time to time.

\section{Problem Statement}

According to the guidelines issued by MQA (2014) for the Code of Practice Accreditation Program (COPPA), the maximum load (teaching activity) of academic staff must be appropriate and balanced compared to other activities. The teaching load is also subject to standards and criteria of the field and based on needs of the related professional body. In general, weekly formal teaching should not exceed 18 contact hours so that academic staff can focus and carry 
out scholarly activities/ research/ consulting services and other administrative tasks. Academic staff should teach with a reasonable number of courses to enable them build and enhance their expertise in any field of study. Accordingly, the number of academic staff must be in accordance with the required standard and the criteria of the field and based on needs of the related professional body.

Table I: Guidelines to Good Practice for Academic Staff Workload

\begin{tabular}{|c|c|c|c|c|c|}
\hline Program & $\begin{array}{l}\text { MQF } \\
\text { Level }\end{array}$ & $\begin{array}{l}\text { Total } \\
\text { Minimum } \\
\text { Credit }\end{array}$ & $\begin{array}{l}\text { Estimated } \\
\text { Number } \\
\text { of } \\
\text { Courses }\end{array}$ & $\begin{array}{l}\text { Number of } \\
\text { Courses for } \\
\text { Each } \\
\text { Academic } \\
\text { Staff } \\
\text { (Maximum) }\end{array}$ & $\begin{array}{l}\text { Number of } \\
\text { Academic } \\
\text { Staff } \\
\text { (Minimum) }\end{array}$ \\
\hline Certificate & 3 & 60 & 15 & 4 & 4 \\
\hline Diploma & 4 & 90 & 23 & 4 & 6 \\
\hline Advanced Diploma & 5 & 40 & 10 & 4 & 3 \\
\hline Graduate Certificate & 6 & $30 *$ & 9 & 3 & 3 \\
\hline Graduate Diploma & 6 & $60 *$ & 17 & 3 & 6 \\
\hline Bachelor Degree & 6 & 120 & 30 & 3 & 10 \\
\hline Postgraduate & 7 & 20 & 5 & 2 & 3 \\
\hline \multicolumn{6}{|l|}{ Certificate } \\
\hline Postgraduate Diploma & 7 & 30 & 8 & 2 & 4 \\
\hline Masters & 7 & 40 & 10 & 2 & 5 \\
\hline \multicolumn{6}{|l|}{ (Coursework \& Mix) } \\
\hline Doctorate & 8 & 80 & 20 & 2 & 10 \\
\hline
\end{tabular}

(Coursework \& Mix)

Table I shows the Guidelines to Good Practice for Academic Staff Workload that all universities should adhere to and that are relegated to the faculty level. For the purpose of calculating the MQA teaching load, it also outlines the criteria based on ratio of students and lecturers according to academic field.

Table II: Standard ratio of academic staff: students for each course and level

\begin{tabular}{|c|c|c|c|c|}
\hline Course & $\begin{array}{l}\text { Certificate, } \\
\text { Diploma and } \\
\text { Advanced } \\
\text { Diploma }\end{array}$ & $\begin{array}{l}\text { Bachelor } \\
\text { Degree, } \\
\text { Certificate and } \\
\text { Graduate } \\
\text { Diploma }\end{array}$ & $\begin{array}{l}\text { Postgraduate } \\
\text { Certificate and } \\
\text { Postgraduate } \\
\text { Diploma, } \\
\text { Masters } \\
\end{array}$ & $\begin{array}{l}\text { Doctorate } \\
\text { (Coursework \& } \\
\text { Mlx) }\end{array}$ \\
\hline Social Science & $1: 30$ & $1: 25$ & $1: 20$ & $1: 12$ \\
\hline $\begin{array}{l}\text { Literature and } \\
\text { Humanities }\end{array}$ & $1: 30$ & $1: 25$ & $1: 20$ & $1: 12$ \\
\hline Science & $1: 25$ & $1: 20$ & $1: 15$ & $1: 9$ \\
\hline Allied Health & & Medicine (1:4) & & $1: 9$ \\
\hline $\begin{array}{l}\text { Science and } \\
\text { Medicine }\end{array}$ & $1: 25$ & $\begin{array}{l}\text { Allied Health } \\
\text { Science }(1: 20)\end{array}$ & $1: 15$ & \\
\hline $\begin{array}{l}\text { Engineering } \\
\text { and } \\
\text { Technology }\end{array}$ & $1: 20$ & $1: 15$ & $1: 15$ & $1: 6$ \\
\hline
\end{tabular}


Table II shows the ratios of academic staff: and the number of students for each courses that should also be complied by all universities in preparing program offerings. The table clearly shows that the ratio for Social Science and Humanities at Certificate, Diploma and Advanced Diploma level is 1:30, Bachelor Degree, and Graduate Certificate and Graduate Diploma is 1:25. Ratio for Postgraduate certificate and Postgraduate Diploma and Master Degree 1:20 and Doctorate (coursework and mix) 1:12. Whereas for Science areas of study Certificate, Diploma and Advanced Diploma are 1:25, Bachelor Degree, and Graduate Certificate and Graduate Diploma are 1:20. Ratio for Postgraduate Certificate and Postgraduate Diploma and Masters 1:25 and Doctoral degree (coursework and mix) 1: 9. For Engineering and Technology at Certificate, Diploma and Advanced Diploma level is 1:20, Bachelor Degree, and Graduate Certificate and Graduate Diploma is 1:15, Postgraduate Certificate and Postgraduate Diploma and Masters Degree level is 1:15 and doctoral degrees (course work and mix) is 1: 6. The nine faculties at UPSI are offering programs at all levels.

University Technology of Malaysia (2015) addressed that the method of computing takes into account the workload of academic staff on the 'total number of hours of staff doing the actual job' in carrying out the three main responsibilities of teaching, research and service within a given time unit. Each activity or task related to a given responsibility will be assigned a specific weight associated with a specific time unit (by hour, week, semester or year). Teaching (UG / PG Teaching \& Supervision (KK)), Research (Research, Publication \& Supervision PG), Administration \& Professional Services (Administration at UTM, Professional Activities, Community Services \& Consultation *. Details of teaching load include lectures, tutorials, practical, studio, supervision, design project, industry training, field / camp work, research project supervision (course work), tutorial lecture and laboratory lecture. While UTHM clearly noted that each academic staff is assigned with 40 hours of minimum weekly workload to implement three (3) key components: (i) Teaching and Supervision, referring to teaching and learning through lectures, tutorials and internships. Whereas Supervision refers to project supervision at the Diploma and Bachelor degree level as well as Industrial Training or Teaching Training. (ii) Research refers to research and project supervision / dissertation / thesis at the Masters and Doctor of Philosophy level. (iii) Administration refers to the appointment of management positions by the University or the Faculty / Center in turn such as Dean, Deputy Dean, Director / Head of Department, Head of Program, Head of Department, Head of Field Panel, Head of Laboratory and other related posts. For details of teaching load without any management positions (Vice Chancellor or Registrar) Exceeds or equal to ( $\geq$ ) 9 credits; credit Coordinator, Lab Head and 6-8 credit equivalent; Panel Head / Head of Department and 3 to 6 credit credits and Less than or equal to $(\leq) 3$ credits for the position of Dean, Director, Deputy Dean, Deputy Director and equivalent. Teaching includes (i) teaching and learning activities at Diploma, Bachelor, Master and Doctorate levels. (ii) The number of students for a Bachelor's degree lecture or tutorial is 30 students. (iii) The number of students for a lecture or lecture level is 15 students.

The workload and accountability of the academic staff professionally challenges their credibility and indirectly influences teaching performance. Teaching as a lecturer covers numerous of tasks including planning, management, delivery, guidance and evaluation. Apart from that, the teaching load of a lecturer exceeds the number of teaching tasks (hours) assigned by the university. Furthermore the high ratio of students to lecturers is alarming in some of the programs offered (Markom et al., 2011). Thus, a study to understand the profile 
of academic staff teaching tasks is necessary to optimize and enhance the use of expertise resources. It is expected to improve the quality of teaching performance in achieving the goals underlined in the Malaysian Education Development Plan 2013-2025 in line with the development of the Industrial Revolution 4.0 (4IR). Moreover, it can also provide an indication of other stakeholders in the university, especially in terms of recruitment of new academic staff resources that each faculty really needs to avoid unnecessary waste of energy.

\section{Study Objectives}

This study aims to identify the workload of academic staff based on teaching load and ratio of academic staff with students to optimize and enhance the use of expertise resources for academic staff at Sultan Idris University of Education.

\section{Research Methodology}

The study design was quantitative with data provided by the Academic Affairs Division (AAD) involving staff at 9 faculties and centers. This method of calculating academic workload involves three aspects of workload, namely, measuring workload for the number of hours an academic staff performs teaching task, writing supervision (project paper, dissertation and thesis) and practical training supervision (teaching training, internship counseling and industry training). In this study, the teaching load of approximately 9 hours and 12 hours a week for the 2017/2018 session involved two semesters namely semester 1 and semester 2 or semester 171 and semester 172. For the purpose of determining lecturers' needs in all faculties, basic ratio computing lecturers and students released by MQA 2014 has been used. 


\section{Results and Discussion \\ Results and Discussion}

Table I Teaching Workload for Semester 171

\begin{tabular}{|c|c|c|c|c|c|}
\hline \multirow[t]{3}{*}{ Faculty } & \multicolumn{5}{|c|}{$\begin{array}{l}\text { Total number of hours of faculty lecturer's workload (teaching, } \\
\text { graduate supervision and supervision of teaching practice) }\end{array}$} \\
\hline & \multicolumn{2}{|c|}{$\begin{array}{l}\text { Supervising lecturers } \\
\text { only }\end{array}$} & \multicolumn{2}{|c|}{ All faculty lecturers } & \multirow{2}{*}{$\begin{array}{l}\text { Average } \\
\text { Percentage } \\
\text { workload by } \\
\text { Faculty [40 } \\
\text { hours per week] }\end{array}$} \\
\hline & 9 hours & $\begin{array}{c}12 \\
\text { hours }\end{array}$ & 9 hours & 12 hours & \\
\hline FPM & 25.5 hours & $\begin{array}{c}28.5 \\
\text { hours }\end{array}$ & $\begin{array}{c}23.9 \\
\text { hours }\end{array}$ & 26.9 hours & $\begin{array}{l}26.2 \text { hours } \\
(65.5 \%)\end{array}$ \\
\hline FTV & 28.2 hours & $\begin{array}{c}31.2 \\
\text { hours }\end{array}$ & $\begin{array}{c}18.7 \\
\text { hours }\end{array}$ & 21.7 hours & $\begin{array}{l}24.9 \text { hours } \\
(62.4 \%)\end{array}$ \\
\hline FSKIK & 23.7 hours & $\begin{array}{c}26.7 \\
\text { hours }\end{array}$ & $\begin{array}{c}19.6 \\
\text { hours }\end{array}$ & 22.6 hours & $\begin{array}{l}23.2 \text { hours } \\
(57.9 \%)\end{array}$ \\
\hline FSSKJ & 20.7 hours & $\begin{array}{c}23.7 \\
\text { hours }\end{array}$ & $\begin{array}{c}18.7 \\
\text { hours }\end{array}$ & 21.7 hours & $\begin{array}{l}23.2 \text { hours } \\
(57.9 \%)\end{array}$ \\
\hline FMSP & 18.9 hours & $\begin{array}{c}21.9 \\
\text { hours }\end{array}$ & $\begin{array}{c}12.8 \\
\text { hours }\end{array}$ & 15.8 hours & $\begin{array}{l}17.4 \text { hours } \\
(43.4 \%)\end{array}$ \\
\hline FBK & 23.9 hours & $\begin{array}{c}26.9 \\
\text { hours }\end{array}$ & $\begin{array}{c}21.7 \\
\text { hours }\end{array}$ & 24.7 hours & $\begin{array}{l}24.3 \text { hours } \\
(60.7 \%)\end{array}$ \\
\hline FPE & 27.4 hours & $\begin{array}{c}30.4 \\
\text { hours }\end{array}$ & $\begin{array}{c}26.9 \\
\text { hours }\end{array}$ & 29.9 Jam & $\begin{array}{c}28.7 \mathrm{Jam} \\
(71.6 \%) \\
\end{array}$ \\
\hline FSK & 20.7 hours & $\begin{array}{c}23.7 \\
\text { hours }\end{array}$ & $\begin{array}{c}17.8 \\
\text { hours }\end{array}$ & 20.8 hours & $\begin{array}{c}20.8 \text { hours } \\
(51.9 \%)\end{array}$ \\
\hline FSM & 16.4 hours & $\begin{array}{c}19.4 \\
\text { hours }\end{array}$ & $\begin{array}{c}19.1 \\
\text { hours }\end{array}$ & 19.1 hours & $\begin{array}{l}19 \text { hours } \\
(46.3 \%)\end{array}$ \\
\hline PBM-PU & 14.9 hours & $\begin{array}{c}17.9 \\
\text { hours }\end{array}$ & $\begin{array}{l}9.17 \\
\text { hours }\end{array}$ & $\begin{array}{l}12.17 \\
\text { hours }\end{array}$ & $\begin{array}{l}13.5 \text { hours } \\
(33.8 \%)\end{array}$ \\
\hline $\begin{array}{l}\text { Average and Percent } \\
\text { of workload } \quad[0 \\
\text { hours a week] }\end{array}$ & $\begin{array}{c}20.1 \text { hours } \\
(52.75 \%)\end{array}$ & $\begin{array}{l}25 \mathrm{Jam} \\
(62.5 \%)\end{array}$ & $\begin{array}{c}18.8 \\
\text { hours } \\
(47 \%) \\
\end{array}$ & $\begin{array}{l}21.5 \text { hours } \\
(53.75 \%)\end{array}$ & 22.12 hours \\
\hline $\begin{array}{l}\text { Average and } \\
\text { Percentage } \\
\text { workload [40 hours a } \\
\text { week] }{ }^{*} \text { Supervising } \\
\text { and Without } \\
\text { Supervising }\end{array}$ & \multicolumn{2}{|c|}{$\begin{array}{l}22.6 \text { hours } \\
(56.4 \%)\end{array}$} & \multicolumn{2}{|c|}{$\begin{array}{l}20.2 \text { hours } \\
(50.4 \%)\end{array}$} & (55.3\%) \\
\hline $\begin{array}{l}\text { Average for overall } \\
\text { percentage }\end{array}$ & \multicolumn{5}{|c|}{$\begin{array}{c}21.4 \\
(53.5 \%)\end{array}$} \\
\hline
\end{tabular}

As shown from Table 1, it is found that the teaching load of the teaching task for semester 171 for teaching and supervising category and teaching only category by faculty is only 9 hours and 12 hours a week. Findings for teaching and supervising category showed a higher weekly 
load of 22.6 Hours (56.4\%) compared to the average load of lecturers who are only teaching with 20.2 Hours (50.4\%). The average teaching load for lecturers teaching and supervising and teaching alone in semester 171 was 21.4 Hours from 40 hours of weekly work load taken into account or $53.5 \%$. The study also showed in terms of teaching load by faculty and language center, it was found that the Faculty of Management and Economics had the highest teaching load of 28.7 Hours or 71.6 per cent followed by the Faculty of Human Development with 26.2 Hours or 65.5 per cent. Meanwhile, six faculties exceed 50 per cent namely Faculty of Engineering and Vocational (FTV), Faculty of Computers and Creative Interactive (FSKIK), Faculty of Music and Performing Arts (FMSP), Faculty of Languages and Communication (FBK) and Faculty of Human Sciences (FSK). While the Faculty of Science and Mathematics (FSM) and the Center for English and General Studies (PBM-PU) is below 50 percent. A study by Academia (2017) for faculty performing 70 per cent teaching, 20 per cent research, 10 percent service is Teaching Faculty and if the task load leads to 60 per cent research, 30 per cent teaching, 10 per cent service is directed to Research Faculty. This finding shows that two faculties namely FPM and FPE achieve educational-oriented faculties, and six faculties toward achieving educational-oriented faculties. This study confirms that the Faculty of Science and Mathematics, which accounts for only $46.3 \%$ of teaching time, is close to research-oriented faculty based on study by Academia (2017), which allocates time to $40 \%$ research, $40 \%$ teaching and $20 \%$ service.

Overall, for both categories of teaching and supervision and teaching alone for 9 hours and 12 hours and the average and workload by faculty still exceed 50 percent of the 40 hours of workload allocated to teaching in semester 171 . The findings of this study are contrary to a study carried out by Collins (2019) which states that most universities in the UK and US share their teaching load by $40 \%, 20 \%$ research and $20 \%$ service. His research also contradicts the teaching load of 40 hours a week, while Collins (2019) study allocates only 37.5 hours for a week workload. A study by (University and College Union (UCU) (2016) found teaching in Wales and Northern Ireland is $70 \%$ teaching, 20\% research and 10 percent service, in terms of 9-hour or 12-week teaching, as per the university's UPSI / TNC (A\&A) /242.2 (26) dated February 8 , which is lecturer load of 9 credits (9 hours) to 12 credits (12 hours); Deputy Director / Deputy Dean / Principal / Head of Department / Coordinator and Dean of 3 credits (3 hours). The study findings are also in contrast to the study of Savvakis et al., (2011) who stated that the teaching load and requirements of the Technological Education Institute of Crete for professors are 10 hours, 12 hours associate professors and 14 hours assistant professors. Nevertheless, this finding is similar with a study by University and College UnionUCU, Ireland (2016) with average hours devoted to lecturing that covers lectures, tutorials and student consultations is 23.8 hours or 46.2 percent. 
Table II Teaching Workload for Semester 172

\begin{tabular}{|c|c|c|c|c|c|}
\hline \multirow[t]{3}{*}{ Faculty } & \multicolumn{5}{|c|}{$\begin{array}{l}\text { Total number of hours of faculty lecturer's workload } \\
\text { (teaching, graduate supervision and supervision of teaching practice) }\end{array}$} \\
\hline & \multicolumn{2}{|c|}{$\begin{array}{l}\text { Supervising lecturers } \\
\text { only }\end{array}$} & \multicolumn{2}{|c|}{ All faculty lecturers } & \multirow{2}{*}{$\begin{array}{l}\text { Average } \\
\text { Percentage } \\
\text { workload by } \\
\text { Faculty [ } 40 \text { hours } \\
\text { per week] }\end{array}$} \\
\hline & 9 hours & 12 hours & 9 hours & 12 hours & \\
\hline FPM & 24.8 hours & 27.8 hours & 21.9 hours & $\begin{array}{c}24.9 \\
\text { hours }\end{array}$ & $\begin{array}{l}24.9 \text { hours } \\
(62.3 \%)\end{array}$ \\
\hline FTV & 25.6 hours & 28.6 hours & 17.3 hours & $\begin{array}{c}20.3 \\
\text { hours }\end{array}$ & $\begin{array}{l}23 \text { hours } \\
(57.4 \%)\end{array}$ \\
\hline FSKIK & 24.4 hours & 27.4 hours & 19.9 hours & $\begin{array}{c}22.9 \\
\text { hours }\end{array}$ & $\begin{array}{l}23.7 \text { hours } \\
(59.1 \%)\end{array}$ \\
\hline FSSKJ & 20.1 hours & 23.1 hours & 18.3 hours & $\begin{array}{c}21.3 \\
\text { hours }\end{array}$ & $\begin{array}{l}20.7 \text { hours } \\
(51.8 \%)\end{array}$ \\
\hline FMSP & 17.9 hours & 20.9 hours & 11.5 hours & $\begin{array}{c}14.5 \\
\text { hours }\end{array}$ & $\begin{array}{l}16.2 \text { hours } \\
(40.5 \%)\end{array}$ \\
\hline FBK & $\begin{array}{l}20.19 \\
\text { hours }\end{array}$ & $\begin{array}{l}23.19 \\
\text { hours }\end{array}$ & $\begin{array}{l}18.89 \\
\text { hours }\end{array}$ & $\begin{array}{l}21.89 \\
\text { hours }\end{array}$ & $\begin{array}{l}21 \text { hours } \\
(52.6 \%)\end{array}$ \\
\hline FPE & 26.7 hours & 29.7 hours & $\begin{array}{l}24.56 \\
\text { hours }\end{array}$ & $\begin{array}{l}27.56 \\
\text { hours }\end{array}$ & $\begin{array}{l}27.1 \text { hours } \\
(67.8 \%)\end{array}$ \\
\hline FSK & 19.1 hours & 22.1 hours & 15.5 hours & $\begin{array}{c}18.5 \\
\text { hours }\end{array}$ & $\begin{array}{c}18.8 \text { hours } \\
(47 \%)\end{array}$ \\
\hline FSM & 16.6 hours & 19.6 hours & $\begin{array}{l}15.29 \\
\text { hours }\end{array}$ & $\begin{array}{l}18.29 \\
\text { hours }\end{array}$ & $\begin{array}{c}17.4 \text { hours } \\
(43.6 \%)\end{array}$ \\
\hline PBM-PU & 12 hours & 15 hours & 9.08 hours & $\begin{array}{l}12.08 \\
\text { hours }\end{array}$ & $\begin{array}{c}12.1 \text { hours } \\
(30.1 \%)\end{array}$ \\
\hline $\begin{array}{l}\text { Average and } \\
\text { Percent of } \\
\text { workload [ } 40 \\
\text { hours a week] }\end{array}$ & $\begin{array}{c}20.7 \text { hours } \\
(51.8 \%)\end{array}$ & $\begin{array}{c}23.7 \text { hours } \\
(59.3 \%)\end{array}$ & $\begin{array}{c}17.2 \text { hours } \\
(43 \%)\end{array}$ & $\begin{array}{c}20.2 \\
\text { hours } \\
(50.5 \%)\end{array}$ & \\
\hline $\begin{array}{l}\text { Average and } \\
\text { Percentage of } \\
\text { workload [ } 40 \\
\text { hours a week] } \\
\text { * Supervising } \\
\text { and Without } \\
\text { Supervising }\end{array}$ & \multicolumn{2}{|c|}{$\begin{array}{c}22.2 \text { hours } \\
(55.5 \%)\end{array}$} & \multicolumn{2}{|c|}{$\begin{array}{c}18.7 \text { hours } \\
(46.7 \%)\end{array}$} & $\begin{array}{c}20.5 \text { hours } \\
(51.2 \%)\end{array}$ \\
\hline $\begin{array}{l}\text { Average for } \\
\text { overall } \\
\text { percentage }\end{array}$ & \multicolumn{5}{|c|}{20.5 hours (51.3\%) } \\
\hline
\end{tabular}

Table II of the study found the teaching load for semester 171 for teaching and supervising workload category and teaching only category by faculty is 9 hours and 12 hours a week. Findings for the teaching and supervising category showed a higher weekly load of 22.2 Hours $(55.5 \%)$ compared to the average teaching load of 18.7 Hours (46.7\%). The average teaching load for lecturers teaching and supervising and teaching alone in semester 172 was 20.5 Hours 
out of 40 hours of weekly work load or $51.3 \%$. The study also showed for teaching load by faculty and language center found that Faculty of Management and Economics had the highest teaching load of 27.1 Hours or 67.8 per cent followed by the Human Development Faculty of 24.9 Hours or 62.53 per cent and six faculties exceeded 50 per cent weekly work load of teaching i.e Faculty of Management and Economics (FPE), Faculty of Human Development (FPM), Faculty of Engineering and Vocational (FTV), Faculty of Computer and Creative Interactive Arts (FSKIK), and Faculty of Language and Communication (FBK). The findings of the study are similar to those reported by Ziker (2016) allocating 62 percent to teaching, with 18 percent devoted to research and 20 percent to administrative and other tasks. While the Faculty of Music Arts (FSMP), Faculty of Human Sciences (FSK), Faculty of Science and Mathematics (FSM) and the Center for English and General Studies (PBM-PU) is less than 50 per cent of teaching workload per week. Overall, both categories for teaching and supervising and teaching alone for 9 hours and 12 hours as well as the average and workload by faculty still exceed 50 percent of the 40 hours of the assigned workload in semester 172. The findings of this study are supported by Algon Quin College (2018) which states that the weekly workload of teaching ranges from 18 hours to 20 hours, which includes face-to-face lectures and tutorials.

The study also considers the needs of lecturers in each faculty based on the 9 hours of teaching hours and 12 hours workload per week for semester 171 and semester 172 . 
INTERNATIONAL JOURNAL OF ACADEMIC RESEARCH IN BUSINESS AND SOCIAL SCIENCES Vol. 11, No. 6, 2021, E-ISSN: 2222-6990 @ 2021 HRMARS

Table III: Lecturers' Requirements of 9 Faculties for Semesters 171 and 172 for 9 Hours and 12 Hours

\begin{tabular}{|c|c|c|c|c|c|c|c|c|}
\hline \multicolumn{5}{|c|}{9 Faculties Semester 171 and 172 (9 hours) } & \multicolumn{4}{|c|}{$\begin{array}{l}9 \text { Faculties Semester } 171 \text { and } 172 \\
\text { (12hours) }\end{array}$} \\
\hline \multirow[t]{2}{*}{ Faculty } & \multicolumn{2}{|c|}{ Semester 171} & \multicolumn{2}{|c|}{ Semester 172} & \multicolumn{2}{|c|}{ Semester 171} & \multicolumn{2}{|c|}{ Semester 172} \\
\hline & $\begin{array}{l}\text { Available } \\
\text { Lecturer }\end{array}$ & $\begin{array}{c}9 \\
\text { hour } \\
\mathrm{s}\end{array}$ & $\begin{array}{l}\text { Available } \\
\text { Lecturer }\end{array}$ & $\begin{array}{c}9 \\
\text { hours }\end{array}$ & $\begin{array}{l}\text { Available } \\
\text { Lecturer }\end{array}$ & $\begin{array}{l}12 \\
\text { hours }\end{array}$ & $\begin{array}{l}\text { Available } \\
\text { Lecturer }\end{array}$ & $\begin{array}{c}12 \\
\text { hours }\end{array}$ \\
\hline FPM & 106 & -35 & 117 & -23 & 106 & -2 & 117 & +12 \\
\hline FTV & 33 & -5 & 35 & -3 & 33 & +5 & 35 & +6 \\
\hline FSKIK & 91 & +1 & 95 & -3 & 91 & +23 & 95 & +22 \\
\hline FSSKJ & 43 & -13 & 44 & -17 & 43 & +1 & 44 & -2 \\
\hline FMSP & 64 & -10 & 68 & -3 & 64 & +8 & 68 & +15 \\
\hline FBK & 94 & -11 & 87 & -23 & 94 & +15 & 87 & +3 \\
\hline FPE & 77 & -15 & 82 & -3 & 77 & +9 & 82 & +19 \\
\hline FSK & 68 & -9 & 73 & -25 & 68 & +11 & 73 & 0 \\
\hline FSM & 101 & -5 & 112 & -7 & 101 & +22 & 112 & +22 \\
\hline $\begin{array}{l}\text { PBM- } \\
\text { PU }\end{array}$ & 36 & 0 & 38 & +3 & 36 & +9 & 38 & +12 \\
\hline Average & & $\begin{array}{l}- \\
10.4\end{array}$ & & -10.4 & & +10.1 & & +10.9 \\
\hline
\end{tabular}

+ extra lecturers; - shortage of lecturers.

Table III findings show that for 171 and 172 semesters, if each lecturer is to teach 9 hours a week, there was a shortage of lecturers in all faculties. On average, the shortage of lecturers for the 171 and 172 semesters was 10.4 lecturers (-10.4). However, if all the lecturers in each faculty were to practice 12 hours a week for both semesters it would appear that there will be extra lecturers for all faculties except for the Faculty of Human Development (FPM) that still shorts of lecturers in the semester 171. For overall average on both 171 and 172 semesters, teaching 12 hours shows an almost equal value of +10.1 and +10.9 number of lecturers. The policy by UPSI states that lecturer teaching at an average of 9 hours to 12 hours a week in line with Middle Tennessee State University's (MTSU) policies and policies set forth 
in Policy 223 related to teaching and credit assignments for courses, which is also similar to the method of calculating the number of lecturers needed for the current semester using credit hours for each course of related field.

For the ratio of academic staff to student (1:30) at diploma level, it was found three diploma programs still lacking of lecturers and seven professorship programs have extra lecturers for semester 172 . While for semester 171 there were four programs that shorts of lecturers and five extra lecturers and one program with 1:30 ratio. Findings of the study is against student and faculty ratios set by the National Quality Assurance Agency for Higher Education (MQA) (2014) which explained that diploma and advanced diploma programs ratio of student and lecturer to be met is 1:30. The shortage and excess of lecturers have implications to the use of lecturer expertise in faculty and department. Meaning, lecturers are committed, encouraged and able to track their learners when numbers are manageable compared to when the students are too many to control Ankwasiize Evarist (2018). In meeting the Ratio 1:25 academic staff with undergraduate students from 31 programs, it was found that 23 departments were short of lecturers and 8 faculties were having extra lecturers. Ratio 1:20 for the graduate program (undergraduate) found 14 programs out of 24 departments offering graduate (undergraduate) programs still lacking lecturers, while 10 departments have extra lecturers in semester 172 . While in semester 171 , there was shortage of lecturers in 16 departments and extra lectures for 8 departments. Incompliance to the ratio that lead to shortage and excess of lecturers are closely related to performance of students (Nizamettin \& Bekir, 2014).

\section{Conclusion}

The results showed the workload measured that did not take into account the number of lecture hours is different with the total load hours. Therefore, a mechanism for estimating the load of teaching tasks should be established for the purpose of ensuring that teaching ratios are as robust as research, publication and consultation to maximize the use of existing expertise at UPSI. To that end, the recruitment of lecturers in the field of shortage of lecturers can be accommodated by lecturers from other faculties; especially to teach university courses and curriculum need to be improved. The faculty and student ratios should also take into account the overall load of the university which is 1:30 ratio of lecturers that is too wide a gap among faculties, thus the imbalance need to be tackled through the coordination of expertise according to needs of the university. The ratios of courses for each department within 30 to 50 people are the right course allocation group to help each faculty to structure program on programs review that should consider 120 credit hours is sufficient for each program to maximize the use of talent resources. The workload of lecturers in terms of supervision and supervision of teaching training must be balanced between lecturers for 40 hours a week. Distribution of post-graduate supervision and supervision of practice and industry training should involve all lecturers. With such measures, action plan can be structured to select academic staff capable of holding administrative tasks based on the workload of each faculty.

\section{Acknowledgement}

Center for Research and Innovation Management Center through Sultan Idris Education University Special Research Grant Fund). [Ref: 2018-0100-106-01 (SPECIAL)] 


\section{References}

Chaudhry, A. A., Malik, M. I., \& Ahmad, I. (2011). Examining the Relationship of Work-Life Conflict and Employee Performance (A Case from NADRA Pakistan), International Journal of Business and Management, 6 (10).

Azman, A. H., Mansor, N., \& Mohamad, Z. (2016). Impak Beban Kerja Terhadap Prestasi Kerja Pensyarah: Kes Kajian Di Politeknik Sultan Mizan Zainal Abidin (Psmza), e-Academia Journal UiTMT, 5(1), 1-11.

Benjamin, O., Olajumoke, C. (2013). Influence of Mental Workload on Job Performance. International Journal of Humanities and Social Science, 3(15), 238-246.

Centre for Academic Development And Training UTHM. (2016). Panduan Bebas Staf Akademik Universiti Tun Hussein Onn.

Chughati, F. D., \&Perveen, U. (2013) A study of Teachers Workload And Job Satisfaction In Public And Private Schools At Secondary Level in Lahore City Pakistan. Asian Journal of Social Sciences \& Humanities, 2(1), 202-214.

Gahlann, V. S. (2014) The Effect of Role Overload and Role Ambiguity on Job Performance of IT Professionals in India, The IUP Journal of Management Research, XIII(3), 37-49.

Ira Pracinasari. (2013). Beban Kerja FisikVs Beban Kerja Mental. Universitas Sebelas Maret, Surakarta.

Abdul Hamid, J., Mohayidin, M. G., Selamat, M. H., Ibrahim, H., Abdullah, R., \& Hashim, R. (2006). Using Algorithm taxonomy to evaluate lecturer workload: A case study of services application prototype in the UM KM Portal.

Kod Amalan Akreditasi Program. (2010). Code of Practice for Programme Accreditation, Edisi Pertama, Agensi Kelayakan Malaysia.

Markom, M., Abdul, N. A., Ariffin, A. K., Abd Wahab, Z., Husain, H., \& Ramli, N. F. R. (2011). Pengukuran Jam Notional Pensyarah Dalam Meningkatkan Prestasi Ahli Akademik Universiti Penyelidikan.Seminar Education Engineering \& Built Environment (PeKA 2011), Kuala Lumpur, Unuversiti Kebangsaan Malaysia.

Basarudin, N. A., Yeon, A. L., Yaacob, N., \& Abdul Rahman, R. (2016). Transformation of higher education status: Issues on faculty workload.The European Proceeding of Social and Behavioural Sciences. International Soft Science Conference Diambil pada 22 Jun 2018 from.https://drive.google.com/file/d/1JZ8tolRqOtdNgnMIMF9AwMAH2Q1Jh1ng/view

Pusat Pembangunan Akademik UPNM. (2015). Dasar Beban Tugas Akademik.

Mustapha, R. (2013). Transforming Education Toward K-economy in Malaysia. International Journal for Educational Studies, 6(1), 1-16.

Collins, R. D. (2019). 100 hours per year of teaching a heavy load for a lecturer. From https://academia.stackexchange.com/users/43544/(Jun 19,2020:12.00pm)

Mustapha, R. (2009). Job Satisfaction Among Vocational Teachers in Malaysia. International Journal for Educational Studies, 1(2), 169-186.

Universiti Malaysia Pahang. (2011). A Guide to Learning and Teaching at UMP.

University of South Wales Prifysgol De Cymru, Acedemic Workload Model. (2014). https://drive.google.com/file/d/1CBQYkEeaeZW5Gv_hqr2ILHF6JDwQ2Urc/view

Koca, N., \& Celika, B. (2014). The Impact of Number of Students per Teacher on StudentAchievement. Global Conference on Contemporary Issues in Education, GLOBE-EDU 2014, 12-14 July 2014,Las Vegas, USA. Procedia-Social and Behavioral Sciences 177 (2015) 65-70.

Workload Survey Report. (2016).Workload is an education issue (University and College Union-UCU, Ireland). 
Ziker, J. (2014) Shows Professors Mork Load Hour And Spend Much Day Meeting. https://www.insidehighered.com/new/2014/04/09/research.

University of South Wales Academic Workload Model. (2014). https://www.ucu.org.uk/media/335/ University-of-South-Wales-academic-workloadmodel-Dec-14/pdf/usw_academicworkloadmodel.pdf.

Evarist, A. (2018) Teacher-Student Ratio on Classroom Practices in Universal. Journal of Emerging Trends in Educational Research and Policy Studies (JETERAPS) 9(4), 167-177 